\title{
Network Ties and Organizational Action: Explaining Variation in Social Service Provision Patterns
}

\author{
Brad R. Fulton ${ }^{1 *}$ \\ ${ }^{1}$ School of Public and Environmental Affairs, Indiana University, Bloomington, IN, USA \\ *Correspondence: 1315 E. 10 ${ }^{\text {th }}$ St., Bloomington, IN 47405, USA. Tel: 1-812-855-6948. E-mail: fulton@indiana.edu
}

Received: April 1, $2016 \quad$ Accepted: April 10, $2016 \quad$ Online Published: June 14, 2016

doi:10.5430/mos.v3n3p1 URL: http://dx.doi.org/10.5430/mos.v3n3p1

\begin{abstract}
This study integrates social capital theory and network analysis to explore the relationship between interorganizational networks and organizational action. It analyzes the collaborative partnerships that religious congregations form to provide social services, and it examines how these ties are associated with the number and types of programs they offer. Using cross-sectional and panel data from a national study of congregations, the analysis finds significant relationships between congregations' interorganizational ties and their social service provision patterns. Congregations that collaborate with other organizations offer more programs, and the effect is even greater for congregations with a diverse portfolio of collaborators. Furthermore, a network analysis indicates that congregations with a similar portfolio of collaborators offer a similar menu of services. This study demonstrates that an organization's collaborative ties, above and beyond its internal characteristics, are significantly associated with both the volume and scope of its activity.
\end{abstract}

Keywords: interorganizational networks, social capital, organizational capacity, social service provision

\section{Introduction}

Social capital research often analyzes how involvement in voluntary organizations benefits individuals and communities. For individuals, being involved in voluntary organizations can generate social capital, which they can mobilize to facilitate action (Burt, 1992; Granovetter, 1974; Lin, 2001). For communities, having their members involved in voluntary organizations can generate social capital, which communities can mobilize to coordinate action (Coleman, 1988; Putnam, 1993). Although it is clear that voluntary organizations contribute to the accumulation of social capital, less is known about how social capital affects voluntary organizations themselves (Hardy, Phillips, \& Lawrence, 2003; Paarlberg \& Varda, 2009; Schneider, 2009). Social capital theory suggests that a voluntary organization can generate social capital for itself by participating in interorganizational collaborations, and the organization can mobilize this capital to increase its capacity for action (Knoke, 1983; Passey \& Lyons, 2006; Zahra, 2010). Social capital theory also suggests that a coalition of organizations established through interorganizational collaborations can generate social capital, which the coalition can mobilize to coordinate the action of its members (Galaskiewicz, Bielefeld, \& Myron, 2006; Knoke, 2009). This study integrates social capital theory and network analysis to explore the relationship between interorganizational networks and organizational action. Specifically, it analyzes the collaborative ties religious congregations form to provide social services, and it examines their association with the number of programs and types of services congregations offer.

\subsection{Theoretical Framework: Social Capital, Social Networks, and Organizational Action}

Social capital is conceptualized as the resources embedded in an actor's network that can be mobilized to facilitate action (Lin, Ensel, \& Vaughn, 1981; Nahapiet \& Ghoshal, 1998). By collaborating with other organizations, an organization can gain access to resources such as expert knowledge, best practices, training, and referrals (Knoke, 1983, 1999). Specifically among nonprofit organizations, collaborative ties can provide access to facilities, human resources, and new funding sources, all of which are associated with an organization's capacity for action (Minzner, Klerman, Markovitz, \& Fink, 2014; Passey \& Lyons, 2006). The amount of external resources to which an organization has access is associated with the size and diversity of its interorganizational network (Burt, 1997; Lin, 
1999b). An organization with more collaborators has access to more resources (Lin \& Dumin, 1986) and an organization with a greater variety of collaborators has access to a greater variety of resources (Burt, 1992; Granovetter, 1973; Son \& Lin, 2008)—both of which can increase the organization's capacity for action.

Having a more extensive and/or diverse collaborator network, however, does not necessarily increase an organization's capacity for action. Organizations can incur substantial costs establishing and maintaining collaborative partnerships, and sometimes the resources expended to find partners, accommodate differences, and build trust exceed the resources acquired through the collaboration (Braunstein, Fulton, \& Wood, 2014; Ebers \& Grandori, 1997; Smith-Doerr \& Powell, 2005). Because interorganizational collaborations might not be beneficial for all organizations, some organizations could increase their productivity by limiting collaborative ties or by functioning as organizational isolates (Burt, 1992; Rogers \& Mulford, 1982).

Social capital is also conceptualized as the common values and priorities of a group that can be mobilized to coordinate action (Coleman, 1988; Putnam, 2000). By extension, a group of organizations can possess shared interests that it can mobilize to coordinate the activity of its members (Baker \& Faulkner, 2009; Knoke, 2009). When an organization joins an interorganizational network, it can influence and be influenced by the shared interests of the network members (Knoke, 2009; Phillips, Lawrence, \& Hardy, 2000). Within collaborative efforts, organizations must negotiate competing interests to arrive at mutually agreeable outcomes (Eden \& Huxham, 2001; Galaskiewicz et al., 2006). Networks can also be a source of information from which organizations learn about new opportunities and adopt new practices (Dimaggio \& Powell, 1983; Galaskiewicz \& Wasserman, 1989; Hardy et al., 2003). Network theory predicts that organizations embedded in similar interorganizational networks will exhibit similar behavior (Borgatti \& Everett, 1992; White \& Reitz, 1983). In particular, organizations that have the same types of collaborators occupy similar network positions and are likely to participate in similar activities.

\subsection{Analytical Focus: Congregations, Collaborators, and Social Service Provision}

To examine the relationship between an organization's collaborator network and the volume and scope of its activity, this study analyzes religious congregations and the collaborative ties they form to provide social services. Congregations are an appropriate unit of analysis for several reasons. First, congregations are the most ubiquitous voluntary organization in the U.S. and they exist in communities throughout the country (Cnaan \& Curtis, 2013). Second, congregations expend resources not only for their internal operations, but also for programs that serve the broader community. Over 80 percent of congregations in the U.S. offer at least one social service program (Chaves \& Anderson, 2008a); by conservative estimates, this proportion represents more than 250,000 congregations (Hadaway \& Marler, 2005). Third, because the resource requirements associated with offering social services often exceed a congregation's capacity, many congregations participate in interorganizational collaborations to provide services (Chaves, 2004; Cnaan, 2002). Among the congregations involved in social service provision, over two-thirds collaborate with outside organizations (Chaves \& Anderson, 2008b). Given congregations' ubiquity, resource scarcity, and propensity to form interorganizational ties, they provide an excellent sample for assessing the relationship between network ties and organizational action.

Congregations contribute more resources toward meeting social needs than any other type of voluntary organization whose primary function is not social service provision (Chaves, 2004; Chaves \& Eagle, 2016). Even though congregations collectively make a substantial contribution to social services, not all congregations contribute equally (Fulton, 2016b; Todd \& Houston, 2013). Congregations vary substantially in the number of programs and types of social services they offer (Chaves \& Tsitsos, 2001; Cnaan, 2002; Unruh \& Sider, 2005; Wuthnow, 2004). Most attempts to explain this variation focus on congregations' internal characteristics, and they ignore congregations' collaborative ties with external organizations. This study broadens the analytical frame by identifying congregations' interorganizational networks and assessing their association with congregations' social service provision patterns.

Among the internal characteristics associated with a congregation providing social services are its resources. Congregations with more resources provide more social services, and a congregation's most important service-related resource is its members (Chaves, 2004; Clerkin \& Grønbjerg, 2007; Wineburg, 2001). In addition to human resources, congregations with more financial resources offer more social services (Ammerman, 2005). Smaller congregations with meager budgets are limited in the social services they can provide because most of their resources go toward organizational survival. Larger congregations, conversely, tend to have greater economic stability and more resources available to support social services (Chaves, 2004).(Note 1)

Another internal factor influencing a congregation's social service activity is its leaders. Clergy play a pivotal role in directing and mobilizing congregational activity, and shifts in a congregation's focus often correspond with changes in its leadership (Warner, 1988). In particular, innovative and entrepreneurial pastors can use their position to 
convince their members to embrace social activism (McRoberts, 2003). Specifically regarding social services, the clergy's education level is positively associated with a congregation's involvement in social service provision (Chaves \& Tsitsos, 2001; Cnaan, Sinha, \& McGrew, 2004).

Beyond resources and leadership, congregations' theological orientation and religious tradition shape their social service activity. Conservative beliefs undermine social activism (Kanagy, 1992), which leads conservative congregations to be less involved in providing social services (Chaves \& Tsitsos, 2001; Wuthnow, 2004). Also, because conservative congregations tend to be less connected with their surrounding communities, they are less likely to recognize and respond to community needs (Beyerlein \& Hipp, 2006). Overall, theologically conservative congregations tend to focus more on meeting people's spiritual needs rather than addressing their material needs. Along with theological orientation, social service provision patterns correspond with religious tradition. Mainline Protestant congregations offer more programs than Catholic and conservative Protestant congregations, which tend to provide a similar number of programs to one another (Chaves \& Tsitsos, 2001; Wuthnow, 1999).

Although research demonstrates a relationship between congregations' internal characteristics and their social service provision patterns, these factors do not explain all of the variation (Polson, 2015). Developing a fuller understanding requires expanding the frame of analysis to include the interorganizational ties congregations form to provide social services (Ammerman, 2005; Campbell, 2011; Fulton, 2011). Rather than being autonomous units driven solely by internal characteristics, congregations are social institutions embedded within a network of interdependent organizations (Granovetter, 1985). In particular, when congregations engage in community outreach, they often develop connections with other organizations through ecumenical alliances, secular coalitions, and other institutional networks (Ammerman, 2005; Schneider, 2006; Wood, 2002). Research on congregation-based social services reveals that most programs are conducted in collaboration with other organizations (Cnaan et al., 2004; Wuthnow, 2000). Eighty-four percent of congregations offering social services have at least one collaborator and 72 percent of all programs are conducted in collaboration with other organizations (Chaves \& Tsitsos, 2001). Establishing collaborative ties has become an institutionalized part of congregations' involvement in social service provision, and, as a result, many social services offered by congregations are embedded within and dependent on interorganizational networks.

Even though organizational collaborators play a substantial role in congregation-based social service provision, little is known about the relationships between a congregation's collaborator network and the volume and scope of its activity. Several studies find that most congregations participate in interorganizational collaborations to provide social services; however, these studies neglect to analyze whether and how collaborative ties influence a congregation's social service activity. (Note 2) Although previous research indicates a significant relationship between a congregation's resources and the number of programs it offers, a congregation's network of collaborators is a resource that is often overlooked. Congregations that collaborate with other organizations can gain access to new resource streams that can increase their capacity to provide social services. Because congregations vary in the number and types of organizations with which they collaborate to provide social services (e.g., government, businesses, nonprofits, etc.), this variation can help explain the variation in congregations' social service activity. Applying social capital theory to congregations as organizational actors suggests that the size and diversity of a congregation's collaborator network are positively associated with the number of social service programs it offers. This leads to the following two hypotheses:

\section{H1: Congregations with a greater number of collaborators offer more social service programs.}

\section{H2: Congregations with a greater diversity of collaborators offer more social service programs.}

The types of organizations with which a congregation collaborates can also influence the types of services it offers. Several studies indicate that when congregations partner with other organizations to provide social services, they often join a network of collaborators (Ammerman, 2005; Chaves, 2004; Cnaan, 2002). By joining these networks, congregations can become exposed to other community needs and opportunities to serve (Mosley, 2010; Wood \& Fulton, 2015). Indeed, a congregation might initially establish a collaborative relationship to implement a particular program, but through the relationship the congregation might also adopt a priority of its collaborator and expand its menu of services. When Wuthnow (2004, p. 58) discusses the relationship between congregations, their collaborators, and the adoption of new social service programs, he describes the congregation as "a node in a number of overlapping networks involving other organizations in the community," and he notes that "ideas, talents, and resources flow back and forth through these channels of cooperation." Wuthnow illustrates how collaborators can influence a congregation's scope of service activity by describing how one congregation's collaboration led to a prominent speaker visiting the church and persuading its members to be more concerned about the broader needs of 
the poor. In Lichterman's (2005) analysis of community service coalitions, he provides several examples of how collaborator networks operate to influence congregations to expand their range of services. He describes instances where coalition members provide information on new programs and encourage other members to become involved.

Institutional theory predicts that as congregations become interconnected with other sectors, they will begin to mimic the practices of those sectors (Galaskiewicz \& Wasserman, 1989). Ammerman (2005) speculates that congregations are likely to emulate the patterns of social service provision practiced by their collaborators, and recent research identifies associations between congregations collaborating with outside organizations and offering particular types of programs (Fulton, 2011; Werber, Derose, Domínguez, \& Mata, 2012; Williams et al., 2015). However, no study has used a nationally representative sample of congregations to differentiate between collaborator types and assess their correlation with the menu of services congregations provide.

This study argues that a congregation's portfolio of collaborators is associated with the types of services it offers. According to network theory, congregations embedded in similar interorganizational networks will exhibit similar behavior (Borgatti \& Everett, 1992; White \& Reitz, 1983). Specifically, congregations that collaborate with similar types of organizations will offer similar types of services. This leads to the following hypothesis:

H3: Congregations with a similar portfolio of collaborators offer a similar menu of social services.

\section{Methods}

\subsection{Sample}

To assess the relationship between a congregation's collaborator network and its social service provision patterns, this study uses cross-sectional and panel data from the National Congregations Study (NCS) - a nationally representative survey of religious congregations (Chaves \& Anderson, 2008b). Wave 2 of the NCS, conducted in 2006-7, had a response rate of 78 percent and collected data from key informants on 1,506 congregations. In addition to the cross-section of congregations sampled for Wave 2, a panel component was added, which surveyed a stratified random sample of congregations that participated in Wave 1 of the NCS. As a result, the NCS has a panel dataset that contains data on the 262 congregations that participated in both waves of the NCS. (Note 3) Because this study focuses on congregations that provide social services, it restricts the sample to congregations that reported sponsoring at least one social service program. (Note 4) The resulting cross-sectional sample contains 1,220 congregations, 825 of which collaborate with at least one other organization to provide their program(s). The resulting panel sample contains 158 congregations, 137 of which collaborate with at least one other organization to provide their program(s). (Note 5)

\subsection{Measures and Analytical Strategy}

The dependent variables for this study are constructed using the number of programs and types of social services a congregation offers. For congregations that sponsor social service programs, the NCS asked respondents to describe each of the programs in an open-ended manner. Interviewers did not limit the number of programs a respondent could mention, and for each program mentioned the interviewer probed for its purpose and recorded the verbatim responses. The NCS created a count variable to tabulate the total number of programs and coded the open-ended responses into 24 dichotomous variables each indicating whether the respondent mentioned that type of service. Among congregations that offer programs, the median number of programs a congregation has is 2 , the mean is 3 , and the maximum is 11. Half of all congregations that provide social services participate in food distribution programs, one-third have programs for serving children, and one-quarter are involved in programs that address physical health needs or build/repair homes. Table 1 displays the descriptive statistics related to congregations' social service provision. 
Table 1. Descriptive Statistics of Congregation-Based Social Services

\begin{tabular}{lc}
\hline Type of service & $\begin{array}{c}\text { Percentage of } \\
\text { congregations } \\
\text { offering the service }\end{array}$ \\
\hline Feeding the hungry & $52 \%$ \\
Serving children or youth & $33 \%$ \\
Addressing physical health needs & $25 \%$ \\
Home building or repair & $25 \%$ \\
Religious programs & $23 \%$ \\
Distributing clothing or blankets & $20 \%$ \\
Serving senior citizens & $16 \%$ \\
Serving homeless people & $15 \%$ \\
Non-religious education & $14 \%$ \\
Disaster relief & $13 \%$ \\
Addressing issues specific to men or women & $13 \%$ \\
Serving people outside the United States & $13 \%$ \\
Providing cash and items for housing needs & $11 \%$ \\
Serving prisoners & $6 \%$ \\
Serving victims of rape or domestic violence & $5 \%$ \\
Cleaning highways or parks & $5 \%$ \\
Volunteering & $4 \%$ \\
Substance abuse programs & $4 \%$ \\
Helping with crime prevention & $2 \%$ \\
Helping people obtain jobs & $2 \%$ \\
Addressing issues of race/ethnicity & $2 \%$ \\
Serving immigrants, migrants, or refugees & $2 \%$ \\
Serving college students or young adults & $1 \%$ \\
\hline Source Naton Congeg
\end{tabular}

Source: National Congregations Study, 2006-7 (Includes only the subset of congregations that offered at least one social service program; $\mathrm{N}=1,220$ )

The independent variables for this study are constructed using the number and types of organizations with which a congregation collaborates to provide social services. For congregations that sponsor social service programs, the NCS asked respondents if their programs are run in collaboration with other organizations. Those that responded affirmatively were asked to name their collaborators. The NCS created a count variable to tabulate the total number of collaborators mentioned. Among congregations that offer programs, 32 percent have no collaborators. Among congregations that collaborate, the median number of collaborators a congregation has is 2 , the mean is 2.2 , and the maximum is 17. For each collaborator mentioned, the NCS coded the verbatim responses into one of eight categories to indicate the type of collaborator. The collaborator types are the government, secular nonprofits, businesses, schools, congregations, denominations, other kinds of secular organizations and other kinds of religious organizations. Two-thirds of all congregations that provide social services have at least one organizational collaborator, one-third collaborate with other congregations, and one-quarter collaborate with nonprofit organizations. To calculate the diversity of a congregation's portfolio of collaborators the analysis uses the Blau index which takes into account both the number of collaborator types and the proportion of each collaborator type represented in the congregation's collaborator network. (Note 6) The Blau index generates a diversity score that ranges from 0 to 1 , and the score can be interpreted as the probability that two randomly selected collaborators of a congregation will be of a different type. Based on this index, a congregation that collaborates with only one type of organization has a diversity score of 0 . (Note 7) As the number of different collaborator types increases and as the proportion of each type becomes more evenly distributed, the congregation's collaborator diversity score approaches 1.

This study also incorporates the following measures of congregations' internal characteristics: the congregation's size (the number of regularly participating adults), a set of dummy variables that distinguish between congregations based on their religious tradition (Catholic, mainline Protestant, conservative Protestant, black Protestant, and non-Christian), another set that differentiates based on how the key informants describe their congregation's 
theological orientation (conservative, moderate, or liberal), and binary variables that indicate whether the congregation has a clergy member who has graduated from seminary or theological school, whether the congregation has a staff member who spends at least 25 percent of his/her time overseeing its social service programs, and whether the congregation received government funding to help run its programs. (Note 8) This study also controls for the congregation's geographic location (southern versus non-southern) and community context (urban versus non-urban). Table 2 displays the descriptive statistics for social service providing congregations and their collaborators.

Table 2. Descriptive Statistics of Social Service Providing Congregations and Their Collaborators

\begin{tabular}{|c|c|c|c|c|}
\hline Variable & $\begin{array}{c}\text { Mean/ } \\
\text { Proportion }\end{array}$ & SD & Min & $\operatorname{Max}$ \\
\hline Number of social service programs & 2.83 & 1.99 & 1 & 14 \\
\hline Has at least one collaborator & .68 & .47 & 0 & 1 \\
\hline Number of collaborators & 1.48 & 1.69 & 0 & 17 \\
\hline \multicolumn{5}{|l|}{ Types of Collaborators } \\
\hline Congregations & .32 & .47 & 0 & 1 \\
\hline Denominations & .03 & .18 & 0 & 1 \\
\hline Other (Religious) & .16 & .37 & 0 & 1 \\
\hline Nonprofit organizations & .25 & .43 & 0 & 1 \\
\hline Government & .10 & .30 & 0 & 1 \\
\hline Schools & .04 & .20 & 0 & 1 \\
\hline Businesses & .03 & .17 & 0 & 1 \\
\hline Other (Secular) & .12 & .32 & 0 & 1 \\
\hline Diversity of Collaborator types & .16 & .27 & 0 & .95 \\
\hline Size of congregation $(\mathrm{x} 100)^{\mathrm{a}}$ & 1.46 & 3.22 & 7 & 140 \\
\hline \multicolumn{5}{|l|}{ Religious Tradition } \\
\hline Mainline Protestant & .20 & .40 & 0 & 1 \\
\hline Roman Catholic & .07 & .25 & 0 & 1 \\
\hline Conservative Protestant & .49 & .50 & 0 & 1 \\
\hline Black Protestant & .22 & .42 & 0 & 1 \\
\hline Non-Christian & .02 & .15 & 0 & 1 \\
\hline \multicolumn{5}{|l|}{ Theological Orientation } \\
\hline Conservative & .62 & .49 & 0 & 1 \\
\hline Moderate & .30 & .46 & 0 & 1 \\
\hline Liberal & .08 & .28 & 0 & 1 \\
\hline Clergy graduated & .64 & .48 & 0 & 1 \\
\hline Has staff for social services & .14 & .35 & 0 & 1 \\
\hline Received government funding & .05 & .23 & 0 & 1 \\
\hline \multicolumn{5}{|l|}{ Geographic Region } \\
\hline Northeast & .13 & .34 & 0 & 1 \\
\hline Midwest & .26 & .44 & 0 & 1 \\
\hline South & .46 & .50 & 0 & 1 \\
\hline West & .15 & .36 & 0 & 1 \\
\hline \multicolumn{5}{|l|}{ Community Context } \\
\hline Urban & .50 & .50 & 0 & 1 \\
\hline Suburban & .21 & .40 & 0 & 1 \\
\hline Rural & .29 & .46 & 0 & 1 \\
\hline
\end{tabular}

Source: National Congregations Study, 2006-7 (N=1,220)

${ }^{a}$ Based on the number of regularly participating adults

The first analysis uses the cross-sectional data and performs a series of zero-truncated Poisson regressions to assess the relationship between the size and diversity of a congregation's collaborator network and the number of programs it offers. (Note 9) Although the cross-sectional models can identify contemporaneous associations, they cannot account for causal order. Panel analyses can be used to provide evidence of causality by demonstrating a relationship 
between $X_{t-1}$ and $Y_{t}$ while controlling for $Y_{t-1}$ (Finkel, 1995). When only two waves of data are available, scholars typically propose one of two statistical methods to control for $\mathrm{Y}$ at time 1: the lagged dependent variable method or the change score method (Allison, 1990; Johnson, 2005). The primary advantage of the change score method is that it controls for the effects of all time-invariant variables whether or not they were measured. As a result, change score models provide unbiased estimates that are not contaminated with the confounding effects of any enduring unmeasured variables, and the estimates can be interpreted as those above and beyond any fixed effects (Liker, Augustyniak, \& Duncan, 1985). (Note 10)

The second analysis uses the change score method on the panel data to estimate the lagged effect of a congregation's collaborator network on its provision of social services, while controlling for the number of programs offered at Wave 1 (Allison, 1990). Specifically, it assesses whether a change in the size and/or diversity of a congregation's collaborator network is associated with a change in the number of programs it offers. Following the recommendations of Allison (1990) and Firebaugh and Beck (1994), this analysis uses the full-difference model, where the change in the number of social service programs a congregation offered between Wave 1 and Wave 2 is regressed on the concurrent change in the size and diversity of the congregation's collaborator network. This analysis also includes the change in the congregation's size as well as changes in theological orientation, clergy's education level, having staff for social services, and receiving government funding. The possible change score values for the dichotomous variables are 1, -1, and 0 . For example, for the variable $\Delta$ with conservative theological orientation, congregations that changed from being theologically liberal or moderate at Wave 1 to being theologically conservative at Wave 2 are coded as 1, congregations that changed from being theologically conservative to being theologically liberal or moderate are coded as -1 , and congregations that did not change their theological orientation are coded as 0 . Table 3 displays the descriptive statistics for the change scores of the panel data. The models for the second analysis are estimated using ordinary least squares regression and control for changes in the time-varying independent variables; the time-invariant control variables, which include the congregation's religious tradition, geographic location, and community context, are not included in the models. (Note 11)

Table 3. Descriptive Statistics of Panel Data_Change Scores (Wave 2 - Wave 1) of Time-Varying Variables ${ }^{\mathrm{a}}$

\begin{tabular}{lcccc}
\hline Variable & $\begin{array}{c}\text { Mean/ } \\
\text { Proportion }\end{array}$ & \multicolumn{1}{c}{ SD } & Min & Max \\
\hline$\Delta$ in number of social service programs & -1.16 & 2.81 & -11 & 10 \\
$\Delta$ in number of collaborators & -1.20 & 3.01 & -10 & 8 \\
$\Delta$ in diversity of collaborator types & -.15 & .42 & -.79 & .78 \\
$\Delta$ in size of congregation & 40.66 & 374.61 & $-6,300$ & 5,700 \\
$\Delta$ with conservative theological orientation & .10 & .43 & -1 & 1 \\
$\Delta$ with having clergy graduated & .04 & .48 & -1 & 1 \\
$\Delta$ with having staff for social services & .01 & .37 & -1 & 1 \\
$\Delta$ with receiving government funding & .04 & .20 & -1 & 1 \\
\hline
\end{tabular}

Source: National Congregations Study panel data from Wave 1 (1998) and Wave 2 (2006-7)

${ }^{a}$ Includes only the subset of congregations that offered at least one social service program in $1998(\mathrm{~N}=158)$

${ }^{\mathrm{b}}$ Based on the number of regularly participating adults

Several methods could be used to examine whether congregations with a similar portfolio of collaborators offer a similar menu of services, yet many of these attribute-based methods face limitations because the dependent variable is a non-exclusive multinomial variable (i.e., a categorical variable in which multiple categories can be selected) (Agresti \& Liu, 2001). Conducting a multinomial logistic regression, which requires exclusivity, is infeasible because constructing a categorical variable with exclusive categories using the 23 different services results in more than thirty million categories. An alternative method uses a marginal logit model, which functionally involves conducting a separate logistic regression for each service type. However, this method does not account for the interdependence among service types (Bilder \& Loughin, 2007). Another option for this analysis is a Poisson multinomial logistic regression, which involves a two-step process that begins by identifying the number of services a congregation offers $(n)$ and then computes the probability of offering a particular combination of services given $n$ (Gilbert \& Modena, 2007). Although this approach is the optimal model using attribute data, the similarity estimates are constrained by the number of services a congregation offers.

The third analysis recognizes the limitations of the attribute-based methods, and instead uses a network-based 
method. Specifically, it performs a two-mode analysis using the cross-sectional data to examine whether congregations with a similar portfolio of collaborators offer a similar menu of services. Unlike attribute-based methods that analyze characteristics of individual actors, this network-based approach analyzes similarities among actors to identify those that occupy equivalent network positions (Knoke \& Kuklinski, 1982; Wasserman \& Faust, 2008). To perform this type of analysis, the attribute dataset is transformed into a relational dataset representing 743,590 congregational dyads. (Note 12) To measure similarities between congregations, a matrix composed of similarity scores for each congregational dyad is constructed for each variable. The similarity measure for the types of social services provided-similar social services - is Pearson's product-moment correlation for each congregational dyad between the 23 dichotomous variables indicating whether a congregation offers a particular type of service. (Note 13) The values for this measure range between -.59 and 1.00, where dyads with high correlation values offer a similar menu of services. The similarity measure for congregations' collaborators-common collaborator types - is Pearson's product-moment correlation for each congregational dyad between the 8 dichotomous variables indicating whether the congregation partners with a particular type of collaborator. The values for this measure range between -1.00 and 1.00 , where dyads with high correlation values have a similar set of collaborator types with which they partner. The control variables for this analysis are similar congregation size, same religious tradition, similar theological orientation, clergy graduated, has staff for social services, received government funding, geographic proximity, and equivalent community context.

Because the 743,590 congregational dyads were constructed through the multiple relations among only 1,220 congregations, the cases are not independent. This dependency of observations, which is characteristic of relational data, produces potential autocorrelation problems that can cause p-values to be overestimated when testing hypotheses. To avoid autocorrelation problems, this analysis uses Quadratic Assignment Procedure (QAP) correlation and regression methods, which assume neither independence of observations nor random sampling of cases from a population (Krackhardt, 1987, 1988). The bivariate analysis assesses the correlations between congregations offering a similar menu of services and each of the independent variables, and the subsequent multivariate analyses perform linear regressions of social service provision patterns (see Appendix A for an extended discussion of QAP analysis).

\section{Results}

For the first analysis, which uses the cross-sectional data, the zero-truncated Poisson regressions in Table 4 show the relationships between the independent variables and the number of programs a congregation offers. Model 1 regresses the number of programs on the congregation's internal characteristics and the control variables. Consistent with previous research, this model indicates that a congregation's size, clergy education level, having staff for social services, and receiving government funding are associated with having more programs, while a congregation's geographic location and community context has no significant relationship with the number of programs it offers. Apart from black Protestant congregations having fewer programs than mainline Protestant congregations, neither religious tradition nor theological orientation is significantly associated with the number of programs a congregation offers. Although previous research indicates that religious tradition and theological orientation are associated with whether a congregation provides services, this analysis indicates that these characteristics are not related to how many programs a service-providing congregation offers. The lack of explanatory power offered by religious tradition and theological orientation reveals an even wider gap in our understanding of the sources of variation in social service activity among service-providing congregations.

In an attempt to fill this gap, the subsequent models analyze the relationship between a congregation's collaborator network and the number of programs it offers. Although previous studies provide evidence that a congregation's internal characteristics determine both who it collaborates with and how many programs it provides (Ammerman, 2005; Chaves \& Tsitsos, 2001), the following models demonstrate a significant relationship between a congregation's collaborator network and the number of programs it offers - even when controlling for the congregation's internal characteristics. Model 2 includes the dichotomous variable indicating whether a congregation has any collaborators, and it indicates that having at least one collaborator is associated with having 33 percent more programs. This outcome is roughly equivalent to the effect of having a staff member dedicated to providing social services. Model 3 includes the count variable representing the number of collaborators a congregation has, and it indicates that an increase in the number of collaborators is associated with having more programs. Each additional collaborator is associated with having 18 percent more programs. Meanwhile, in this model, clergy education level, being black Protestant, and receiving government funding become insignificant. Model 4 includes the continuous 
variable indicating the diversity of the congregation's collaborator network, and it indicates that an increase in the diversity of collaborator types is associated with having significantly more programs. Model 5 includes both variables representing the number and diversity of collaborators a congregation has, and it indicates that the number and diversity of collaborators remain significant even when included in the same model. In the models that account for the number of collaborators, receiving government funding becomes insignificant. This finding indicates that although government funding can provide resources to help congregations run more programs, the stronger predictor is the size of a congregation's collaborator network. Consistent with social capital theory, the analysis suggests that congregations with a greater number and variety of collaborators have access to more resources, and thus can offer more programs.

Table 4. Zero-Truncated Poisson Regressions on the Number of Programs a Congregation Offers [anti-logs displayed]

\begin{tabular}{|c|c|c|c|c|c|}
\hline & Model 1 & Model 2 & Model 3 & Model 4 & Model 5 \\
\hline Size of congregation ${ }^{\mathrm{a}}$ & $\begin{array}{l}1.172^{* *} \\
(.059)\end{array}$ & $\begin{array}{l}1.162^{* *} \\
(.058)\end{array}$ & $\begin{array}{l}1.124 * * \\
(.050)\end{array}$ & $\begin{array}{l}1.151^{* *} \\
(.053)\end{array}$ & $\begin{array}{l}1.124 * * \\
(.056)\end{array}$ \\
\hline \multicolumn{6}{|l|}{ Religious tradition ${ }^{b}$} \\
\hline Roman Catholic & $\begin{array}{c}.694 \\
(.148)\end{array}$ & $\begin{array}{l}.716 \\
(.150)\end{array}$ & $\begin{array}{l}.786 \\
(.104)\end{array}$ & $\begin{array}{l}.796 \\
(.147)\end{array}$ & $\begin{array}{l}.804 \\
(.106)\end{array}$ \\
\hline Conservative Protestant & $\begin{array}{l}.870 \\
(.087)\end{array}$ & $\begin{array}{c}.909 \\
(.089)\end{array}$ & $\begin{array}{l}1.024 \\
(.086)\end{array}$ & $\begin{array}{c}.967 \\
(.088)\end{array}$ & $\begin{array}{l}1.033 \\
(.086)\end{array}$ \\
\hline Black Protestant & $\begin{array}{l}.644^{* *} \\
(.084)\end{array}$ & $\begin{array}{l}.685^{* *} \\
(.092)\end{array}$ & $\begin{array}{l}.871 \\
(.113)\end{array}$ & $\begin{array}{l}.800 \\
(.102)\end{array}$ & $\begin{array}{l}.890 \\
(.094)\end{array}$ \\
\hline Non-Christian & $\begin{array}{l}.919 \\
(.152)\end{array}$ & $\begin{array}{l}0.893 \\
(.147)\end{array}$ & $\begin{array}{c}.987 \\
(.145)\end{array}$ & $\begin{array}{l}1.009 \\
(.139)\end{array}$ & $\begin{array}{l}1.003 \\
(.138)\end{array}$ \\
\hline Theologically conservative $^{c}$ & $\begin{array}{c}.994 \\
(.075)\end{array}$ & $\begin{array}{l}1.018 \\
(.076)\end{array}$ & $\begin{array}{l}1.054 \\
(.070)\end{array}$ & $\begin{array}{l}1.015 \\
(.072)\end{array}$ & $\begin{array}{l}1.051 \\
(.070)\end{array}$ \\
\hline Clergy graduated & $\begin{array}{l}1.277^{*} \\
(.132)\end{array}$ & $\begin{array}{l}1.237^{*} \\
(.129)\end{array}$ & $\begin{array}{l}1.169 \\
(.113)\end{array}$ & $\begin{array}{l}1.205 \\
(.118)\end{array}$ & $\begin{array}{l}1.163 \\
(.112)\end{array}$ \\
\hline Has staff for social services & $\begin{array}{l}1.335^{*} \\
(.163)\end{array}$ & $\begin{array}{l}1.370^{*} \\
(.167)\end{array}$ & $\begin{array}{l}1.357^{*} \\
(.163)\end{array}$ & $\begin{array}{l}1.380^{* *} \\
(.162)\end{array}$ & $\begin{array}{l}1.365^{* *} \\
(.162)\end{array}$ \\
\hline Received government funding & $\begin{array}{l}1.534^{*} \\
(.260)\end{array}$ & $\begin{array}{l}1.491^{*} \\
(.246)\end{array}$ & $\begin{array}{l}1.268 \\
(.156)\end{array}$ & $\begin{array}{l}1.423^{*} \\
(.210)\end{array}$ & $\begin{array}{l}1.267 \\
(.158)\end{array}$ \\
\hline South & $\begin{array}{c}.904 \\
(.067)\end{array}$ & $\begin{array}{c}.889 \\
(.065)\end{array}$ & $\begin{array}{l}.840^{* *} \\
(.056)\end{array}$ & $\begin{array}{c}.869^{*} \\
(.060)\end{array}$ & $\begin{array}{l}.841^{* *} \\
(.056)\end{array}$ \\
\hline Urban & $\begin{array}{l}1.012 \\
(.083)\end{array}$ & $\begin{array}{l}1.037 \\
(.084)\end{array}$ & $\begin{array}{l}1.043 \\
(.076)\end{array}$ & $\begin{array}{c}.999 \\
(.078)\end{array}$ & $\begin{array}{l}1.037 \\
(.076)\end{array}$ \\
\hline Has at least one collaborator & & $\begin{array}{l}1.334 * * \\
(.137)\end{array}$ & & & \\
\hline Number of collaborators & & & $\begin{array}{l}1.178^{* * *} \\
(.016)\end{array}$ & & $\begin{array}{l}1.157^{* * *} \\
(.017)\end{array}$ \\
\hline Diversity of collaborator types & & & & $\begin{array}{l}2.71 * * * \\
(.304)\end{array}$ & $\begin{array}{l}1.300^{*} \\
(.152)\end{array}$ \\
\hline Constant & 1.247 & 1.013 & .999 & 1.052 & .978 \\
\hline Log pseudo likelihood & -1803.800 & -1788.209 & -1672.494 & -1729.931 & -1669.415 \\
\hline $\begin{array}{l}* \mathrm{p}<.05, * * \mathrm{p}<.01,{ }^{* * *} \mathrm{p}<.001 \\
\text { Number of congregations }=1,22 \\
\text { Robust standard errors in parent } \\
{ }^{\mathrm{a}} \text { Based on the number of regula } \\
{ }^{\mathrm{b}} \text { Reference group Mainline Prot } \\
{ }^{\mathrm{c}} \text { Reference group Theologically }\end{array}$ & $\begin{array}{l}\text { es } \\
\text { participa } \\
\text { ant }\end{array}$ & dults (lc & & & \\
\hline
\end{tabular}

Turning to the second analysis, which uses the panel data, the change score models in Table 5 show the standardized estimates for the relationships between the change in the number and diversity of collaborators between Wave 1 and Wave 2 and the concurrent change in the number of programs. Model 1 regresses the dependent variable on the 
time-varying control variables, and it indicates that a change in the congregation's size is the only variable significantly associated with a change in the number of programs. This model suggests that the effects of clergy education level, having staff for social services, and receiving government funding observed in the cross-sectional models might be spurious (i.e., they reflect correlations with some unobserved time-invariant variables that affect the number of programs a congregation offers). Models 2 and 3 include the variables representing the change in the number of collaborators and the change in the diversity of collaborator types respectively, and both indicate a positive relationship above and beyond the controls and any fixed effects. (Note 14) Compared to the change in congregation size, the magnitude of the standardized effect associated with a change in number of collaborators is four times greater and the change in the diversity of collaborator types is nearly three times greater. Summarizing the first two analyses, the cross-sectional analysis demonstrates that the size and diversity of a congregation's collaborator network are related to the number of programs it offers, and the change score analysis, which controls for the number of programs at Wave 1, provides evidence for the hypothesized causal direction of this relationship.

Table 5. Standardized Coefficients from OLS Regression Models Estimating the Change in the Number of Programs a Congregation Offers between Wave 1 and Wave 2

\begin{tabular}{lccc}
\hline & Model 1 & Model 2 & Model 3 \\
\hline$\Delta$ in size of congregation ${ }^{\mathrm{a}}$ & $.385^{* * *}$ & $.171^{* *}$ & $.260^{* * *}$ \\
& $(.373)$ & $(.284)$ & $(.295)$ \\
$\Delta$ with conservative theological orientation & .125 & .061 & .097 \\
& $(.583)$ & $(.402)$ & $(.468)$ \\
$\Delta$ with having clergy graduated & .053 & .000 & .016 \\
& $(.368)$ & $(.368)$ & $(.476)$ \\
$\Delta$ with having staff for social services & .008 & .018 & -.004 \\
& $(.470)$ & $(.431)$ & $(.464)$ \\
$\Delta$ with receiving government funding & -.026 & -.056 & -.059 \\
& $(.530)$ & $(.678)$ & $(.826)$ \\
$\Delta$ in number of collaborators & & $.679 * * *$ & \\
& & $(.067)$ & \\
$\Delta$ in diversity of collaborator types & & & $.467 * * *$ \\
& & & $(.304)$ \\
$\mathrm{R}^{2}$ & & & .381 \\
\hline${ }^{*} \mathrm{p}<.05, * * \mathrm{p}<.01, * * * \mathrm{p}<.001$ & & & \\
Number of congregations $=158$ & & & \\
Robust standard errors in parentheses & & &
\end{tabular}

The third analysis uses the cross-sectional data and performs a two-mode network analysis to examine whether congregations with a similar portfolio of collaborators offer a similar menu of services. Table 6 displays the descriptive statistics for the dependent variable and each of the independent variables constructed for this analysis. Also displayed are the QAP matrix correlation results of the observed correlation between congregations offering similar social services and each independent variable. (Note 15) The results indicate a significant correlation between a congregation's collaborator types and the menu of services it offers. 
Table 6. Descriptive Statistics and QAP Matrix Correlation between Similar Social Services and Each of the Independent Variables

\begin{tabular}{|c|c|c|c|c|c|c|}
\hline Variable & Type & Description & Min & $\operatorname{Max}$ & Mean & $\begin{array}{c}\text { Pearson } \\
\text { correlation } \\
\text { coefficient }\end{array}$ \\
\hline Similar social services & Continuous & $\begin{array}{l}\text { The correlation between congregation } i \text { and } j \text { 's } \\
\text { social services }\end{array}$ & -.59 & 1.00 & .16 & - \\
\hline Common collaborator types & Continuous & $\begin{array}{l}\text { The correlation between congregation } i \text { and } j \text { 's } \\
\text { collaborator types }\end{array}$ & -1.00 & 1.00 & .14 & $.03 * * *$ \\
\hline Similar congregation size $\mathrm{e}^{\mathrm{a}}$ & Continuous & $\begin{array}{l}\text { The more similar the size of congregation } i \\
\text { and } j \text {, the higher the value }\end{array}$ & 0.00 & 7.60 & 6.05 & $.05^{* * *}$ \\
\hline Same religious tradition & Binary & $\begin{array}{l}1 \text { if congregation } i \text { and } j \text { are from the same } \\
\text { religious tradition; otherwise } 0\end{array}$ & 0.00 & 1.00 & .27 & $.02 * * *$ \\
\hline Similar theological orientation & Continuous & $\begin{array}{l}\text { The more similar the theological orientation } \\
\text { of congregation } i \text { and } j \text {, the higher the value }\end{array}$ & 0.00 & 2.00 & 1.33 & -.01 \\
\hline Clergy graduated & Binary & $\begin{array}{l}1 \text { if the clergy of congregation } i \text { and } j \text { have } \\
\text { advanced degrees; otherwise } 0\end{array}$ & 0.00 & 1.00 & .71 & $.06^{* * *}$ \\
\hline Has staff for social services & Binary & $\begin{array}{l}1 \text { if congregation } i \text { and } j \text { have staff assigned to } \\
\text { help with social service programs; otherwise } 0\end{array}$ & 0.00 & 1.00 & .04 & .01 \\
\hline Received government funding & Binary & $\begin{array}{l}1 \text { if congregation } i \text { and } j \text { received government } \\
\text { funding; otherwise } 0\end{array}$ & 0.00 & 1.00 & .00 & $.01 *$ \\
\hline Geographic proximity & Binary & $\begin{array}{l}1 \text { if congregation } i \text { and } j \text { are located in the } \\
\text { same region of the country; otherwise } 0\end{array}$ & 0.00 & 1.00 & .28 & .00 \\
\hline Equivalent community context & Binary & $\begin{array}{l}1 \text { if congregation } i \text { and } j \text { are located in the } \\
\text { same type of community context; otherwise } 0\end{array}$ & 0.00 & 1.00 & .52 & .01 \\
\hline
\end{tabular}

$* \mathrm{p}<.05, * * \mathrm{p}<.01, * * * \mathrm{p}<.001$

$\mathrm{N}=743,590$ dyads among 1,220 congregations

Number of random permutations $=2,000$

${ }^{a}$ Based on the number of regularly participating adults (logged)

Table 7 provides the standardized coefficients from the QAP regression analysis that estimates the relationship between congregations having common collaborator types and offering similar social services, while controlling for other shared affiliations and characteristics (see Appendix A for an explanation of how to interpret the $\mathrm{R}^{2}$ values). Standardizing the values of the coefficients enables a straightforward comparison of the average association between each shared affiliation or characteristic and congregations' social service provision patterns. A positive coefficient corresponds with similarity while a negative coefficient corresponds with dissimilarity, and the p-value measures the likelihood of this correspondence occurring by chance. Model 1 regresses the measure of similar social services on each of the control variables, and the results indicate that being similar in size, sharing the same religious tradition, having clergy with similar education levels, and receiving government funding are all associated with offering similar types of services. This finding indicates, for example, that Catholic congregations offer a menu of services that differ significantly from the menu of services offered by other religious traditions. It also indicates that the types of services congregations offer differ depending on whether they receive government funding. On the other hand, the 
analysis finds no relationship between congregations that have a staff person dedicated to providing social services and offering similar types of services, nor are congregations located in similar community contexts or regions of the country more likely to provide similar types of services.

Table 7. QAP Regression of Similar Social Services on Common Collaborator Types and Measures of Shared Characteristics

\begin{tabular}{|c|c|c|}
\hline & Model 1 & Model 2 \\
\hline \multirow[t]{2}{*}{ Similar congregation size ${ }^{a}$} & $.046^{* * *}$ & $.046^{* * *}$ \\
\hline & $(.000)$ & $(.000)$ \\
\hline \multirow[t]{2}{*}{ Same religious tradition } & $.011^{*}$ & $.011^{*}$ \\
\hline & $(.012)$ & $(.021)$ \\
\hline \multirow[t]{2}{*}{ Similar theological orientation } & -.007 & -.007 \\
\hline & $(.199)$ & $(.188)$ \\
\hline \multirow[t]{2}{*}{ Clergy graduated } & $.051 * * *$ & $.051 * * *$ \\
\hline & $(.000)$ & $(.001)$ \\
\hline \multirow[t]{2}{*}{ Has staff for social services } & .010 & .010 \\
\hline & $(.124)$ & $(.122)$ \\
\hline \multirow[t]{2}{*}{ Received government funding } & $.008^{*}$ & $.008^{*}$ \\
\hline & $(.042)$ & $(.045)$ \\
\hline \multirow[t]{2}{*}{ Geographic proximity } & -.002 & -.002 \\
\hline & $(.365)$ & $(.368)$ \\
\hline \multirow[t]{2}{*}{ Equivalent community context } & .001 & .001 \\
\hline & $(.446)$ & $(.453)$ \\
\hline \multirow[t]{2}{*}{ Common collaborator types } & & $.028 * * *$ \\
\hline & & $(.000)$ \\
\hline$R^{2}$ & $.006^{* * *}$ & $.007 * * *$ \\
\hline \multicolumn{3}{|l|}{$* \mathrm{p}<.05, * * \mathrm{p}<.01, * * * \mathrm{p}<.001$} \\
\hline \multicolumn{3}{|c|}{ Standardized regression coefficients } \\
\hline \multicolumn{3}{|c|}{$\mathrm{N}=743,590$ dyads among 1,220 congregations } \\
\hline \multicolumn{3}{|c|}{ Number of random permutations $=2,000$} \\
\hline \multicolumn{3}{|l|}{ QAP proportions in parentheses } \\
\hline${ }^{\mathrm{a}}$ Based on the number of regular & Iсірап) & 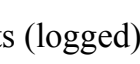 \\
\hline
\end{tabular}

Model 2 includes the measure of common collaborator types and the results indicate a significant relationship between congregations having a similar portfolio of collaborators and offering a similar menu of services. (Note 16) The magnitude of the relationship is greater than those associated with a congregation's religious tradition, theological orientation, staffing allocation, or funding sources. This finding indicates, for example, that a similar 
menu of services is offered among congregations that have only faith-based collaborators, and the menu of services offered by a congregation that has a school in its portfolio of collaborators is similar to the menu of services offered by other congregations that collaborate with schools. Identifying specific portfolios of collaborators and the menu of services associated with each of them could be accomplished through a complex cluster analysis; however, such an analysis is beyond the scope of this study. The primary purpose of this analysis is to demonstrate that a congregation's portfolio of collaborators is significantly associated with the types of services it offers.

One possible counterargument is that the relationship between services and collaborators is unidirectional because certain types of services require specific types of collaborators. This analysis, however, provides evidence for the relationship occurring in the opposite direction (i.e., collaborators influencing services). The results indicate that a congregation's portfolio of collaborators is associated with the congregation's entire menu of services, not just with the services offered in collaboration with other organizations. This observation suggests that while a congregation's programming priorities can influence who it collaborates with, the congregation's collaborator network can influence the types of services the congregation offers.

\section{Discussion}

Most congregations are involved in providing social services. They vary substantially, however, in the number of programs and types of services they offer. While most studies attempt to explain this variation by focusing on congregations' internal characteristics, this study exposes the limitations of this approach and broadens the analytical frame by analyzing congregations' collaborator networks. Although previous studies document the types of organizations congregations collaborate with to provide social services, these studies neglect to analyze how these collaborators might influence the volume and scope of a congregation's social service activity. By integrating social capital theory and network analysis, this study demonstrates that the size and diversity of a congregation's collaborator network are positively associated with the number of programs it offers, and it finds a significant relationship between a congregation's portfolio of collaborators and the types of services it offers.

The variables most consistently associated with the number of programs a congregation offers are those related to its resources. A congregation's size, having staff for social services, and receiving government funding are all indicators of its resources and they are all positively associated with having more programs. Similarly, a congregation's collaborator network is another measure of its resources. Congregations often lack sufficient internal resources to run social service programs on their own, and many collaborate with other organizations as a way to acquire additional resources. Collaborators not only provide resources for the initial program, but also have the potential to provide resources for additional programs. This resource provision is consistent with social capital theory, which predicts that the more collaborators a congregation has, the more access to resources it has to support additional programs. Likewise, a congregation with a diverse collaborator network has access to a greater variety of resources, which can enable it to offer more programs.

While the number of programs a congregation offers is related to the amount of resources it has, the types of services a congregation offers is related to its external ties. Being affiliated with the same religious tradition, having clergy with ties to institutions of higher education, and having the government as a funding source each corresponds with offering a similar menu of services. Furthermore, congregations with ties to similar organizational collaborators offer similar services. Although a congregation might initially select collaborators that will help it accomplish its programming objectives, these collaborators can expose the congregation to other community needs and encourage it to expand its range of services. The previously mentioned studies by Wuthnow (2004) and Lichterman (2005) provide examples of collaborators influencing congregations to adopt new programs, but few studies have examined the underlying processes associated with a congregation's collaborator network and the types of services it offers.

Given the limited data, the following examples represent three plausible scenarios illustrating how this process could occur. A congregation wants to start a tutoring program, so it decides to collaborate with a local school. As the members of the congregation interact with school officials, they learn that many of the students lack sufficient nutrition, and as a result, the congregation decides to set up a food distribution program. Another congregation wants to help people in their community who are unemployed, so it collaborates with a local nonprofit organization to start a job training program. The nonprofit organization also has a prison education program that helps prisoners earn their GED, and eventually the nonprofit asks the congregation to participate in this program as well. A third congregation decides to collaborate only with its denomination in providing social services. Consequently, the services it provides reflect the priorities of its denomination. In each scenario, the collaborating organization exposes the congregation to particular needs and influences the congregation to adopt a new program that reflects its priorities. 
It is also common for community organizations to initiate partnerships with congregations to help carry out their programs (Cnaan, 2002; Fulton \& Wood, 2012; Wineberg, Ahmed, \& Sills, 1997). For example, public health agencies often collaborate with congregations to implement community-based health initiatives (Williams et al., 2015). In other scenarios, organizations like Alcoholics Anonymous and the Red Cross will ask congregations to collaborate with them by providing meeting space and volunteers (Ammerman, 2005). In instances when an organization recruits a local congregation to co-sponsor a program, the collaborating organization directly influences the congregation's involvement in providing a particular type of service.

Clearly, there are multiple pathways by which congregations arrive at new programs and there are several factors that influence congregations along the way. According to Wuthnow (2004), the question remains unanswered as to how congregations decide to sponsor particular service programs. Furthermore, he asserts that this process cannot be understood solely by analyzing congregations' internal characteristics. The primary empirical contribution of this study is to establish that a congregation's collaborator network, above and beyond its internal characteristics, is significantly associated with the number of programs and types of services it offers. The panel analysis provides evidence for the hypothesized causal direction, but analyses using only two waves of data are limited in their capacity to determine causality (Finkel, 1995). Developing a better understanding of the causal processes underlying the relationship between a congregation's collaborator network and the services it provides will require three waves of data along with extended qualitative case studies.

\section{Conclusion}

This study has implications for the broader field of organizational studies. Most organizations are embedded within a network of interrelated institutions that can influence their activity. Analyses that focus exclusively on organizations' internal characteristics, without giving attention to the networks in which they are embedded, fail to account for the relationship between network ties and organizational action. Expanding the analytical frame to include interorganizational collaborations reveals that an organization's collaborator network is significantly associated with both the volume and scope of the organization's activity.

Research on organizations lacks comprehensive theoretical and empirical explanations of how social capital formed through interorganizational ties can enable and constrain action (Knoke, 2009). This study offers a more comprehensive model for explaining organizational action by integrating social capital theory and network analysis to examine both the content and structure of interorganizational networks. The social capital and social networks literatures are complementary, and combining them can yield richer theory, improve model specification, and produce better predictions (Lin, 1999a; Moody \& Paxton, 2009). Social capital theory provides a conceptual framework for analyzing the content of a network, and network analysis provides methods for describing the network's structure and generating valid measures of social capital (Burt, 2000). Together, they can be used to better explain the relationships between interorganizational networks and organizational activity (Walker, Kogut, \& Shan, 1997). Scholars can measure the size and diversity of an organization's network to estimate the quantity and variety of resources available to the organization and the association between the network's size and diversity and the organization's capacity for action. Researchers can also analyze the structural position of organizations within collaborator networks to identify commonalities among otherwise dissimilar organizations and to predict an organization's behavior by observing the behavior of organizations in different networks that occupy equivalent positions. By specifying both the content and structure of interorganizational networks, scholars can better understand the processes by which an organization's network ties can influence its capacity for action and scope of activity.

\section{References}

Agresti, A., \& Liu, I. (2001). Strategies for modeling a categorical variable allowing multiple category choices. Sociological Methods \& Research, 29(4), 403-434. http://dx.doi.org/10.1177/0049124101029004001

Allison, P. D. (1990). Change scores as dependent variables in regression analysis. Sociological Methodology, 20, 93-114. http://dx.doi.org/10.2307/271083

Ammerman, N. T. (2005). Pillars of Faith: American Congregations and Their Partners. Berkeley: University of California Press.

Baker, W., \& Faulkner, R. R. (2009). Social capital, double embeddedness, and mechanisms of stability and change. American Behavioral Scientist, 52(11), 1531-1555. http://dx.doi.org/10.1177/0002764209331525 
Bartkowski, J. P., \& Regis, H. A. (2003). Charitable Choices: Religion, Race, and Poverty in the Post-welfare Era. New York: New York University.

Beyerlein, K., \& Hipp, J. R. (2006). From pews to participation: The effect of congregation activity and context on bridging civic engagement. Social Problems, 53(1), 97-117. http://dx.doi.org/10.1525/sp.2006.53.1.97

Bielefeld, W., \& Cleveland, W. S. (2013). Faith-based organizations as service providers and their relationship to government. Nonprofit and Voluntary Sector Quarterly, 42(3), 468-494. http://dx.doi.org/10.1177/0899764013485160

Bilder, C. R., \& Loughin, T. M. (2007). Modeling association between two or more categorical variables that allow for multiple category choices. Communications in Statistics - Theory and Methods, 36(2), 433-451. http://dx.doi.org/10.1080/03610920600974419

Borgatti, S. P., \& Everett, M. G. (1992). Notions of position in social network analysis. Sociological Methodology, 22(1), 1-35. http://dx.doi.org/10.2307/270991

Borgatti, S. P., Everett, M. G., \& Freeman, L. C. (2002). Ucinet for Windows: Software for social network analysis. Analytic Technologies, Harvard.

Braunstein, R., Fulton, B. R., \& Wood, R. L. (2014). The role of bridging cultural practices in racially and socioeconomically diverse civic organizations. American Sociological Review, 79(4), 705-725. http://dx.doi.org/10.1177/0003122414538966

Burris, V. (2005). Interlocking directorates and political cohesion among corporate elites. American Journal of Sociology, 111(1), 249-283. http://dx.doi.org/10.1086/428817

Burt, R. S. (1992). Structural Holes. Cambridge: Harvard University Press.

Burt, R. S. (1997). The contingent value of social capital. Administrative Science Quarterly, 42(2), 339-365. http://dx.doi.org/10.2307/2393923

Burt, R. S. (2000). The network structure of social capital. Research in Organizational Behavior, 22, 345-423. http://dx.doi.org/10.1016/s0191-3085(00)22009-1

Campbell, D. (2011). Reconsidering the implementation strategy in faith-based policy initiatives. Nonprofit and Voluntary Sector Quarterly, 40(1), 130-148. http://dx.doi.org/10.1177/0899764009349847

Chaves, M. (2004). Congregations in America: Cambridge: Harvard University Press.

Chaves, M., \& Anderson, S. (2008a). Continuity and change in American congregations: Introducing the second wave of the National Congregations Study. Sociology of Religion, 69(4), 415-440.

Chaves, M., \& Anderson, S. (2008b). National Congregations Study: Cumulative datafile and codebook. Durham, NC: Duke University, Department of Sociology.

Chaves, M., \& Eagle, A. (2016). Congregations and social services: An update from the third wave of the National Congregations Study. Religions, 7(5), 55. http://dx.doi.org/10.3390/rel7050055

Chaves, M., \& Tsitsos, W. (2001). Congregations and social services: What they do, how they do it, and with whom. Nonprofit and Voluntary Sector Quarterly, 60(4), 660-683. http://dx.doi.org/10.1177/0899764001304003

Chaves, M., \& Wineburg, B. (2010). Did the faith-based initiative change congregations? Nonprofit and Voluntary Sector Quarterly, 39(2), 343-355. http://dx.doi.org/10.1177/0899764009333955

Clerkin, R. M., \& Grønbjerg, K. A. (2007). The capacities and challenges of faith-based human service organizations. Public Administration Review, 67(1), 115-126. http://dx.doi.org/10.1111/j.1540-6210.2006.00701.x

Cnaan, R. (2002). The Invisible Caring Hand: American Congregations and the Provision of Welfare: New York: New York University Press.

Cnaan, R., \& Curtis, D. (2013). Religious congregations as voluntary associations: An overview. Nonprofit and Voluntary Sector Quarterly, 42(1), 7-33. http://dx.doi.org/10.1177/0899764012460730

Cnaan, R., Sinha, J., \& McGrew, C. (2004). Congregations as social service providers: Services, capacity, culture, and organizational behavior. Administration in Social Work, 28(3), 47-68. http://dx.doi.org/10.1300/J147v28n03_03

Coleman, J. S. (1988). Social capital in the creation of human capital. American Journal of Sociology, 94, 95-120. http://dx.doi.org/10.1086/228943 
Dimaggio, P., \& Powell, W. (1983). The iron cage revisited: Institutional isomorphism and collective rationality in organizational fields. American Sociological Review, 48(2), 147-160. http://dx.doi.org/10.2307/2095101

Ebers, M., \& Grandori, A. (1997). The forms, costs, and development dynamics of interorganizational networking. In M. Ebers (Ed.), The Formation of Inter-organizational Networks (pp. 265-286). New York: Oxford University Press.

Eden, C., \& Huxham, C. (2001). The negotiation of purpose in multi-organizational collaborative groups. Journal of Management Studies, 38(3), 373-391. http://dx.doi.org/10.1111/1467-6486.00241

Finkel, S. E. (1995). Causal Analysis with Panel Data. Thousand Oaks, CA: Sage. http://dx.doi.org/10.4135/9781412983594

Firebaugh, G., \& Beck, F. D. (1994). Does economic growth benefit the masses? Growth, dependence, and welfare in the Third World. American Sociological Review, 59(5), 631-653. http://dx.doi.org/10.2307/2096441

Fulton, B. R. (2011). Black churches and HIV/AIDS: Factors influencing congregations' responsiveness to social issues. Journal for the Scientific Study of Religion, 50(3), 617-630. http://dx.doi.org/10.1111/j.1468-5906.2011.01579.x

Fulton, B. R. (2016a). Organizations and survey research: Implementing response enhancing strategies and conducting nonresponse analyses. Sociological Methods \& Research, http://dx.doi.org/10.1177/0049124115626169

Fulton, B. R. (2016b). Trends in addressing social needs: A longitudinal study of congregation-based service provision and political participation. Religions, 7(5), 51-57. http://dx.doi.org/10.3390/rel7050051

Fulton, B. R., \& Wood, R. L. (2012). Interfaith community organizing: Emerging theological and organizational challenges. International Journal of Public Theology, 6(4), 398-420. http://dx.doi.org/10.1163/15697320-12341252

Galaskiewicz, J., \& Wasserman, S. (1989). Mimetic processes within an interorganizational field: An empirical test. Administrative Science Quarterly, 34(3), 454-479. http://dx.doi.org/10.2307/2393153

Galaskiewicz, J., Bielefeld, W., \& Myron, D. (2006). Networks and organizational growth: A study of community based nonprofits. Administrative Science Quarterly, 51(3), 337-380.

Gilbert, C. L., \& Modena, F. (2007). Models for non-exclusive multinomial choice, with application to Indonesian rural households. Department of Economics, University of Trento.

Granovetter, M. (1973). The strength of weak ties. American Journal of Sociology, 78(6), 1360-1380. http://dx.doi.org/10.1086/225469

Granovetter, M. (1974). Getting a Job. Chicago: University of Chicago Press.

Granovetter, M. (1985). Economic action and social structure: The problem of embeddedness. American Journal of Sociology, 91(3), 481-510. http://dx.doi.org/10.1086/228311

Hadaway, C. K., \& Marler, P. L. (2005). How many Americans attend worship each week? An alternative approach to measurement. Journal for the Scientific Study of Religion, 44(3), 307-322. http://dx.doi.org/10.1111/j.1468-5906.2005.00288.x

Hardy, C., Phillips, N., \& Lawrence, T. B. (2003). Resources, knowledge and influence: The organizational effects of interorganizational collaboration. Journal of Management Studies, 40(2), 321-347. http://dx.doi.org/10.1111/1467-6486.00342

Johnson, D. (2005). Two-wave panel analysis: Comparing statistical methods for studying the effects of transitions. Journal of Marriage \& Family, 67(4), 1061-1075. http://dx.doi.org/10.1111/j.1741-3737.2005.00194.x

Kanagy, C. (1992). Social action, evangelism, and ecumenism: The impact of community, theological, and church structural variables. Review of Religious Research, 34(1), 34-50. http://dx.doi.org/10.2307/3511444

Knoke, D. (1983). Organization sponsorship and influence reputation of voluntary associations. Social Forces, 61(4), 1065-1087. http://dx.doi.org/10.2307/2578279

Knoke, D. (1999). Organizational networks as social capital. In R. Leenders \& S. Gabbay (Eds.), Corporate social capital and liability. Dordrecht, Netherlands: Kluwer Press. http://dx.doi.org/10.1007/978-1-4615-5027-3_2

Knoke, D. (2009). Playing well together: creating corporate social capital in strategic alliance networks. American 
Behavioral Scientist, 52(12), 1690-1708. http://dx.doi.org/10.1177/0002764209331533

Knoke, D., \& Kuklinski, J. H. (1982). Network Analysis. Thousand Oaks, CA: Sage.

Krackhardt, D. (1987). QAP partialling as a test of spuriousness. Social Networks, 9(2), 171-186. http://dx.doi.org/10.1016/0378-8733(87)90012-8

Krackhardt, D. (1988). Predicting with networks: Nonparametric multiple regression analysis of dyadic data. Social Networks, 10(4), 359-381. http://dx.doi.org/10.1016/0378-8733(88)90004-4

Lichterman, P. (2005). Elusive Togetherness: Church Groups Trying to Bridge America's Divisions. Princeton: Princeton University Press. http://dx.doi.org/10.1515/9781400842957

Liker, J. K., Augustyniak, S., \& Duncan, G. J. (1985). Panel data and models of change: A comparison of first difference and conventional two-wave models. Social Science Research, 14(1), 80-101. http://dx.doi.org/10.1016/0049-089X(85)90013-4

Lin, N. (1999a). Building a network theory of social capital. Connections, 22(1), 28-51.

Lin, N. (1999b). Social networks and status attainment. Annual Review of Sociology, 25, 467-487. http://dx.doi.org/10.1146/annurev.soc.25.1.467

Lin, N. (2001). Social Capital: A Theory of Social Structure and Action. New York: Cambridge University Press. http://dx.doi.org/10.1017/CBO9780511815447

Lin, N., \& Dumin, M. (1986). Access to occupations through social ties. Social Networks, 8(4), 365-385. http://dx.doi.org/10.1016/0378-8733(86)90003-1

Lin, N., Ensel, W. M., \& Vaughn, J. C. (1981). Social resources and strength of ties: Structural factors in occupational status attainment. American Sociological Review, 46(4), 393-405. http://dx.doi.org/10.2307/2095260

McRoberts, O. M. (2003). Streets of Glory: Church and Community in a Black Urban Neighborhood. Chicago: University of Chicago.

Minzner, A., Klerman, J. A., Markovitz, C. E., \& Fink, B. (2014). The impact of capacity-building programs on nonprofits: A random assignment evaluation. Nonprofit and Voluntary Sector Quarterly, 43(3), 547-569. http://dx.doi.org/10.1177/0899764013491013

Moody, J., \& Paxton, P. (2009). Building bridges: Linking social capital and social networks to improve theory and research. American Behavioral Scientist, 52(11), 1491-1506. http://dx.doi.org/10.1177/0002764209331523

Mosley, J. E. (2010). Organizational Resources and Environmental Incentives: Understanding the Policy Advocacy Involvement of Human Service Nonprofits. Social Service Review, 84(1), 57-76. http://dx.doi.org/10.1086/652681

Nagpaul, P. S. (2003). Exploring a pseudo-regression model of transnational cooperation in science. Scientometrics, 56(3), 403-416. http://dx.doi.org/10.1023/A:1022335021834

Nahapiet, J., \& Ghoshal, S. (1998). Social capital, intellectual capital, and the organizational advantage. Academy of Management Review, 23(2), 242-266. http://dx.doi.org/10.2307/259373

Paarlberg, L. E., \& Varda, D. M. (2009). Community carrying capacity: A network perspective. Nonprofit and Voluntary Sector Quarterly, 38(4), 597-613. http://dx.doi.org/10.1177/0899764009333829

Passey, A., \& Lyons, M. (2006). Nonprofits and social capital: Measurement through organizational surveys. Nonprofit Management and Leadership, 16(4), 481-495. http://dx.doi.org/10.1002/nml.122

Phillips, N., Lawrence, T. B., \& Hardy, C. (2000). Inter-organizational collaboration and the dynamics of institutional fields. Journal of Management Studies, 37(1), 23-44. http://dx.doi.org/10.1111/1467-6486.00171

Polson, E. C. (2015). Social diversity and civic engagement: The effects of ethnic and social heterogeneity on the community involvement of American congregations. Nonprofit and Voluntary Sector Quarterly, 44(5), 968-987. http://dx.doi.org/10.1177/0899764014548424

Putnam, R. D. (1993). Making Democracy Work: Civic Traditions in Modern Italy. Princeton: Princeton University Press.

Putnam, R. D. (2000). Bowling Alone: The Collapse and Revival of American Community. New York: Simon and Schuster. http://dx.doi.org/10.1145/358916.361990 
Reingold, D. A., Pirog, M., \& Brady, D. (2007). Empirical evidence on faith-based organizations in an era of welfare reform. Social Service Review, 81(2), 245-283. http://dx.doi.org/10.1086/515832

Rogers, D. L., \& Mulford, C. L. (1982). The historical development. In D. L. Rogers \& D. A. Whetten (Eds.), Interorganization coordination: Theory, research, and implementation ( $p$. 32-53). Ames: Iowa State University.

Schneider, J. A. (2006). Social Capital and Welfare Reform: Organizations, Congregations, and Communities: New York: Columbia University Press.

Schneider, J. A. (2009). Organizational social capital and nonprofits. Nonprofit and Voluntary Sector Quarterly, 38(4), 643-662. http://dx.doi.org/10.1177/0899764009333956

Smith-Doerr, L., \& Powell, W. W. (2005). Networks and economic life. In N. J. Smelser \& R. Swedberg (Eds.), The Handbook of Economic Sociology, 2nd Ed. (pp. 379-402). Princeton: Princeton University Press.

Son, J., \& Lin, N. (2008). Social capital and civic action: a network-based approach. Social Science Research, 37(1), 330-349. http://dx.doi.org/10.1016/j.ssresearch.2006.12.004

Todd, N. R., \& Houston, J. D. (2013). Examining patterns of political, social service, and collaborative involvement of religious congregations: A latent class and transition analysis. American Journal of Community Psychology, 51(3-4), 442-438. http://dx.doi.org/10.1007/s10464-012-9561-3

Unruh, H. R., \& Sider, R. J. (2005). Saving Souls, Serving Society: Understanding the Faith Factor in Church-based Social Ministry. New York: Oxford University Press. http://dx.doi.org/10.1093/0195161556.001.0001

Walker, G., Kogut, B., \& Shan, W. (1997). Social capital, structural holes and the formation of an industry network. Organization Science, 8(2), 109-125. http://dx.doi.org/10.1287/orsc.8.2.109

Warner, R. S. (1988). New Wine in Old Wineskins: Evangelicals and Liberals in a Small-town Church. Berkeley: University of California Press.

Wasserman, S., \& Faust, K. (2008). Social Network Analysis: Methods and Applications. New York: Cambridge University Press.

Werber, L., Derose, K. P., Domínguez, B. X., \& Mata, M. A. (2012). Religious congregations' collaborations: With whom do they work and what resources do they share in addressing HIV and other health issues? Health Education \& Behavior, 39(6), 777-788. http://dx.doi.org/10.1177/1090198111434595

White, D. R., \& Reitz, K. P. (1983). Graph and semigroup homomorphisms on networks of relations. Social Networks, 5(2), 193-234. http://dx.doi.org/10.1016/0378-8733(83)90025-4

Williams, M. V., Haas, A., Griffin, B. A., Fulton, B. R., Kanouse, D. E., Bogart, L. M., \& Derose, K. P. (2015). Predictors of the existence of congregational hiv programs: Similarities and differences compared with other health programs. American Journal of Health Promotion, 29(6), 225-235. http://dx.doi.org/10.4278/ajhp.130531-QUAN-280

Wineberg, R. J., Ahmed, F., \& Sills, M. (1997). Local human service organizations and the local religious community during an era of change: A community study. Journal of Applied Social Sciences, 21(2), 85-94.

Wineburg, R. J. (2001). A Limited Partnership: The Politics of Religion, Welfare, and Social Service. New York: Columbia University Press.

Wood, R. L. (2002). Faith in Action: Religion, Race, and Democratic Organizing in America. Chicago: University of Chicago Press.

Wood, R. L., \& Fulton, B. R. (2015). A Shared Future: Faith-Based Community Organizing for Racial Equity and Ethical Democracy. Chicago: University of Chicago Press. http://dx.doi.org/10.7208/chicago/9780226306162.001.0001

Wuthnow, R. (1999). Mobilizing civic engagement: The changing impact of religious involvement. In T. Skocpol \& M. P. Fiorina (Eds.), Civic Engagement in American Democracy (pp. 331-363). Washington, DC: Brookings Institution.

Wuthnow, R. (2000). Linkages between churches and faith-based nonprofits: Aspen Institute, Nonprofit Sector Research Fund.

Wuthnow, R. (2004). Saving America?: Faith-Based Services and the Future of Civil Society: Princeton: Princeton 
University Press.

Zahra, S. A. (2010). Harvesting family firms' organizational social capital: A relational perspective. Journal of Management Studies, 47(2), 345-366. http://dx.doi.org/10.1111/j.1467-6486.2009.00894.x

\section{Notes}

Note 1. As a congregation gathers more resources it will not necessarily direct them toward providing social services, unless that is one of its stated goals (Ammerman, 2005). Consequently, even though congregations with more resources tend to offer more services, the amount they offer is not necessarily proportional to their size.

Note 2. A handful of studies examine the effects of congregations collaborating specifically with the government to provide social services (Bartkowski \& Regis, 2003; Chaves \& Wineburg, 2010; Reingold, Pirog, \& Brady, 2007); however, these studies are limited in that they analyze only one type of congregational collaborator (Bielefeld \& Cleveland, 2013).

Note 3. The sampling procedure used by the NCS yields a probability-proportional-to-size sample, which means that larger congregations are more likely than smaller congregations to be included in the sample. The data for this study has been weighted to undo the probability-proportional-to-size feature of the NCS sample.

Note 4. This study does not focus on identifying the determinants of whether a congregation provides social services; rather, it focuses on congregations that provide social services and examines the relationship between a congregation's collaborator network and its social service provision patterns. Furthermore, if a congregation did not offer social services, the NCS did not ask it any of the collaborator questions. As a result, this study analyzes only those congregations that provide social services.

Note 5. The panel sample includes every congregation that reported sponsoring at least one social service program at Wave 1 regardless of whether it sponsored any programs at Wave 2.

Note 6. Diversity $=1-\sum_{k} \rho_{k}^{2}$ where $k$ represents the collaborator type and $\rho_{k}$ is the proportion of collaborators of type $k$. The diversity scores have been normalized to range from 0 to 1 by multiplying by $k /(k-1)$ where $k=8$.

Note 7. Congregations with no collaborators were coded 0 for this variable.

Note 8 . The variable for the congregation's revenue has a large number of missing values $(435 ; 29 \%)$, and nonresponse diagnostics indicate that this variable contains significant nonresponse bias (Fulton, 2016a). Since a congregation's size is an adequate proxy for its revenue, the analysis controls for the congregation's access to internally derived resources using its number of regularly participating adults.

Note 9. Because every congregation in the sample offers at least one social service program, the zero-truncated Poisson regression is more appropriate to use than the standard Poisson regression because the zero-truncated regression is designed to model count data for which the value zero cannot occur.

Note 10. Furthermore, when using two-wave panel data in which $\mathrm{X}$ is measured contemporaneously with $\mathrm{Y}$ at both time points, it is not appropriate to use the lagged dependent variable method because it assumes a temporal ordering from $Y_{1}$ to $X_{1}$ to $Y_{2}$ (Allison, 1990). Also, because the lagged dependent variable method includes $Y_{1}$ as an independent variable in the analysis, the presence of measurement error in $\mathrm{Y}$ can lead to biased estimates. The change score method avoids this problem because $Y_{1}$ is not included as an independent variable (Johnson, 2005).

Note 11. This analysis assumes that the time-invariant controls have identical effects at both time points and thus can be omitted from the equation without biasing the estimates (Allison, 1990).

Note 12. Number of dyads $=[\mathrm{N}(\mathrm{N}-1) / 2]=1220 \times 1219 / 2=743,590$.

Note 13. For services that did not fit into any of the 23 categories, the NCS placed them in a $24^{\text {th }}$ category called "Other." Because this portion of the analysis focuses on the similarity of services offered, this category was omitted.

Note 14. To assess the robustness of the results, semi-difference models and models that include the number of programs offered at Wave 1 as an independent variable were tested. These models, compared with the change score models, yielded no significant differences in estimating the relationship between a congregation's collaborator network and the number of programs it offers.

Note 15. The test of parameter significance is based on 2,000 permutations. When the observed value of the coefficient is positive, its statistical significance is based on the proportion as large and when the coefficient is negative, it is based on the proportion as small. Although not displayed, the function also generates the average 
correlation value derived from the random permutations. As expected, the average value consistently approaches zero.

Note 16. This finding addresses a counterargument that a congregation's internal characteristics determine both its collaborator network and the menu of services it provides by demonstrating a significant relationship between a congregation's collaborator network and the menu of services it provides even when controlling for the congregation's internal characteristics.

\section{Appendix A - Quadratic Assignment Procedure (QAP) Analyses}

A QAP analysis begins by calculating the initial parameter estimates, and then estimates the probabilities of obtaining these coefficients using a nonparametric technique. In this second step, the analysis randomly permutes the rows and columns of the dependent variable matrix, recalculates the parameter estimates, and compares the original coefficients with the coefficients obtained from the random permutations. Analogous to a simulation, this reordering procedure rearranges the cases assigned to each set of values while maintaining the underlying structure of the network data. The QAP analysis obtains a sampling distribution of the estimates by repeating this process many (e.g., $2,000)$ times. By comparing the observed coefficient value with the estimates from the permutations, the analysis calculates the proportion of permuted estimates that are as extreme as the observed value.

Statistical significance of the correlation is based on the proportion of random measures that are as extreme as the observed measure. From these proportions, the probability that the observed network structure (and the observed coefficient values) could have occurred by chance can be estimated. The proportions represent the p-values for the initial estimates, where small p-values (i.e., <.05) suggest a low likelihood that the observed relationship between the matrices occurred by chance. For example, if only 100 out of 2,000 permutations of the matrix yield estimated regression coefficients greater than or equal to the observed value (or less than or equal to for negative values), then the probability that the observed coefficient is the result of random sampling error is approximately .05 (Burris, 2005). Simulation studies demonstrate that regardless of the degree of autocorrelation, QAP regression produces unbiased standard error estimates that can be interpreted like the estimates of standard correlation and regression models (Krackhardt, 1988).

The QAP analyses in this study are performed using the QAP correlation function and the Full Partialling method in the QAP Matrix Regression module in the UCINET 6.0 network analysis program (Borgatti, Everett, \& Freeman, 2002). The regression tool performs a standard multiple regression across corresponding cells of the dependent and independent matrices, and it assesses the significance of the $\mathrm{R}^{2}$ value and regression coefficients by comparing them with the values generated from the random permutations. Statistical significance is derived from the proportion of randomly generated coefficient values that exceed the observed value. For the $\mathrm{R}^{2}$ value and each coefficient, the program counts the proportion of random permutations that yielded a coefficient as extreme as the initial value. This proportion represents the p-values for the QAP regression coefficients. Small p-values (i.e., < .05) suggest a low likelihood that the observed relationship between the matrices occurred by chance.

The relatively small size of $R^{2}$ values can be easily misinterpreted; the small $R^{2}$ values are a by-product of how the dyadic variables were constructed. Because congregational ties through common collaborator types only represent a small percentage of the 771,903 dyads in the sample, the explained variance associated with these ties will be equivalently small (Burris, 2005). Consequently, the models are expected to generate relatively low $\mathrm{R}^{2}$ values and model fitness can be assessed by comparing the corresponding $\mathrm{R}^{2}$ values. The key measure is the statistical significance of the $R^{2}$ value rather than its size (Nagpaul, 2003). In each model, the $R^{2}$ value is statistically significant $(p<.001)$, since none of the random trials yield an $R^{2}$ as large as the observed value. 